Desertion as Localism: Army Unit Solidarity and Group Norms in the U.S. Civil War Author(s): Peter S. Bearman

Source: Social Forces, Vol. 70, No. 2 (Dec., 1991), pp. 321-342

Published by: Oxford University Press

Stable URL: https://www.jstor.org/stable/2580242

Accessed: 25-03-2019 15:59 UTC

JSTOR is a not-for-profit service that helps scholars, researchers, and students discover, use, and build upon a wide range of content in a trusted digital archive. We use information technology and tools to increase productivity and facilitate new forms of scholarship. For more information about JSTOR, please contact support@jstor.org.

Your use of the JSTOR archive indicates your acceptance of the Terms \& Conditions of Use, available at https://about.jstor.org/terms

Oxford University Press is collaborating with JSTOR to digitize, preserve and extend access to Social Forces 


\title{
Desertion As Localism: Army Unit Solidarity and Group Norms in the U.S. Civil War*
}

\author{
PETER S. BEARMAN, University of North Carolina at Chapel Hill
}

\begin{abstract}
Drawing from the experiences of 3,126 enlisted men from North Carolina who fought for the Confederacy in the U.S. Civil War, this article focuses on the determinants of desertion. I argue that men deserted because their identity as Southerners was eroded by an emergent localism, sustained and organized within the Confederate army. Desertion rates were highest in companies that evidenced a high degree of local homogeneity - company solidarity thus bred rather than reduced desertion rates. There is no support for any of the historical models of desertion that search for individual-level determinants, such as social class, occupation, status, family structure, age, or time of enlistment. Finally, contextual variables seem to be weak proxies for the central variable accounting for desertion - the emergence of a localist identity.
\end{abstract}

Mother there is soldiers deserting every day \& I hope that they will continue to desert until this war is ended.

Private T.W. Gaither, April 3, 1863 (Hardy n.d.)

In the final months of World War II, German soldiers continued to oppose the Allied forces despite overwhelming odds and knowledge that they faced certain defeat (Shils \& Janowitz 1948). In Vietnam and Afghanistan, small and poorly supplied resistance armies ultimately defeated, in struggles that lasted for years, armed forces with vast material and manpower resources at their disposal. In marked contrast, the Confederate South, in control of resources and manpower that, relative to the opposing forces, were greater than those of numerous successful resistance movements, was overwhelmed by Union forces within 18 months of its first major military setbacks. Why did the South lose the Civil War, and why did it lose so quickly?

\footnotetext{
- Tim Long, Kathy Giuffre, and Michael McKenna assisted with the collection of data. Richard Melvin graciously made available his materials on the men of the 39th Regiment. Charles Ragin and John Padgett helped frame the argument at an early stage of the project, and I thank them for their help. This article benefited from the comments of Glenn Deane, Philip O'Connell, and Ronald Rindfuss. Financial assistance from the Institute for Research in Social Science, University of North Carolina at Chapel Hill, is gratefully acknowledged. Direct all correspondence to the author, Department of Sociology, University of North Carolina, Chapel Hill, NC 27599-3210.
}

() The University of North Carolina Press

Social Forces, December 1991, 70(2):321-342 
A popular answer is that the agrarian South was overwhelmed by the industrial North's superior capacity to harness and deploy manpower and material resources (Donald 1960). Contemporaries in the South may have found comfort in this argument, but recently many historians have focused on the internal conflicts arising from ideological and structural cleavages in antebellum Southern society as the cause of the collapse of Southern morale (Beringer et al. 1986; Durden 1972; Escott 1978; McPherson 1982; Owsley [1925] 1961; Wiley 1943).

This new focus on internal ruptures has taken numerous forms. Escott (1978) suggests, for example, that Confederate military policies, which exempted planters who owned more than 20 slaves from active service, heightened the nascent class conflict between the large planter aristocracy and the mass of yeomen farmers over the course of the war. As their standard of living declined, yeomen farmers increasingly came to resent the elite and the Confederacy, which earlier had appeared to serve their interests (Watson 1985). The poor did not want to fight a rich man's war while the rich stood by. Historians have also focused on the emergence of conflict over the issue of slavery. Beringer et al. (1986) suggest that as the war continued, many Southerners harbored increasing doubts about the justness of slavery. These doubts led men, especially those from outside the "slavebelt" who did not have a vested economic interest in slavery, to withdraw their support for the Confederacy and the war effort. Both arguments have a similar logic - the Civil War brought to light class antagonisms latent in antebellum Southern society and consequently crippled the sense of Southern identity and nationalism that flourished at secession.

Historians have also suggested that bitter battles among the elite over state rights fragmented Southern nationalism (Donald 1960; Owsley [1925] 1961). Dissonance between the reality of a strongly centralized Confederate state and the ideal of state rights led some elites to withdraw their support for the war and to sabotage the Confederacy from within. Contemporaries did not fail to notice the irony of a state rights movement led by a central authority more powerful than the Union from which the Southern states had seceded.

These arguments have cumulated in a new historical vision of the Civil War that suggests that structural and ideological cleavages undermined Confederate unity (Escott \& Crow 1986). In the context of a weak and poorly articulated national identity, these nascent cleavages undermined the bases for collective action and lead inexorably to Northern victory. From this perspective, the South lost the Civil War not because the North was able to deploy more resources and men but because it was unable to sustain a collective identity as a Confederate state in the wake of structural cleavages that crosscut and eroded the bases for national sentiment.

Confederates had little to fight for, so when the going got rough, they quit. As Beringer et al. (1986) write:

After three years of essentially successful defense against powerful invading forces these prolonged strains proved more than Confederate nationalism could bear and ... Confederates, by thousands of individual decisions, abandoned the struggle for and allegiance to the Confederate States of America. 


\section{The Meaning of Desertion}

This article focuses on one tangible trace of the decision to abandon the Confederacy - desertion - as a way to make sense of the structure of internal dissent to the war. My main goal is to induce a pattern in the desertion rate that will elucidate why the Confederacy unraveled so quickly. The focus is on the sociological rather than the historical significance of desertion. Although some may find this a naive distinction, I simply note that the historian is likely to treat desertion as an independent variable - related causally to a stream of events - whereas the sociologist treats desertion as a dependent variable, the meaning of which (beyond, of course, idiosyncratic motives of individuals) is revealed only through analysis of its correlates. The strategy adopted to make sense of desertion is similar to the one Durkheim (1951) used to understand suicide.

Of course, desertion was perceived by Confederate leaders as a critical problem. Almost from the start of the war, Confederate leaders voiced concerns over high desertion rates, claiming that desertion contributed directly to military defeats and, worse, demoralized the home front (Lonn 1928). Their concerns were justified, for Southern desertions had a major impact on the Confederate army's ability to prosecute the war, especially after 1863. In the final months of fighting, about two-thirds of Lee's army disappeared from the front; and in the west, high desertion rates reduced Confederate troop strength well before Sherman's famed march to sea.

From a sociological perspective, desertion rates provide a relatively straightforward metric by which one can measure, and thus interpret, the source and structure of internal dissent and war resistance. The pattern of desertion provides insight into the sudden collapse of the Confederacy. This article shows that a part of the new historical vision is correct, that men did abandon the Confederacy because an ephemeral Confederate/Southern identity unraveled. But rather than identify basic structural and ideological cleavages as the critical factors, I show that the Confederacy unraveled because old localisms that were nurtured within the Confederate army emerged as the central bases for identity. These localisms had nothing to do with class or status interests arising from civil society, as Escott (1978) and Beringer et al. (1986) would suggest. Nor were they tied to lofty issues in politics or statecraft. But the adoption of a localist identity did mean that soldiers stopped thinking of themselves as Southerners fighting a Southern cause, and when they did so, they deserted the army.

The South lost the war largely because soldiers replaced their newfound Southern identity with their old local identity and thereby discovered that they had no reason to fight. I support this claim with an analysis of the army careers of over 3,000 Southerners who volunteered and fought.

\section{Historical and Sociological Models of Desertion}

Historians have sought to explain desertion in the Civil War by focusing on individual-level differences between deserters and stayers (Bardolph 1964; Barrett 1963; Lonn 1928; Reid 1981; Tatum 1934), yet the pattern of desertions 
from the Confederate army shows that these models are seriously inadequate. There are no social characteristics at the individual level that distinguish stayers from deserters. This claim challenges the historical accounts of Southern desertion, which assert that desertion was motivated by heterogeneous interests arising from positions in civil society. But poor men and rich men deserted at the same rate as farmers, planters, laborers, and craftsmen. Neither wealth nor occupation was associated with higher desertion rates. Class antagonism may have emerged in the South during the war years, the poor may have increasingly felt that they were fighting a rich man's war, but neither class conflict nor feelings of resentment drove soldiers to desert. Heterogeneous individual interests fail to predict desertion.

In other military contexts, desertion has historically been inversely related to company/unit solidarity (Shils \& Janowitz 1948; Stouffer et al. 1949). Sociological models of desertion suggest that the context of service - the company and primary group - plays an important role in determining desertion. A main contribution of the sociological analyses of desertion in war thus has been to identify the pivotal role of social solidarity within units, which binds men into military society and consequently forges identity as a soldier. Theoretically, in units where social relations are strong, soldiers must overcome enormous social constraint in order to desert. Likewise, when social solidarity in the primary unit is weakened, each soldier is theoretically freed from constraint and may pursue individual rather than group ends. In this sense, desertion is kin to apostasy, for just as the true believer is at greatest risk to apostasy when isolated from other believers, the individual soldier is at greatest risk to desertion when the primary groups in military society are weak and disaggregated. The absence of social solidarity within the primary group largely facilitates desertion.

The pattern of desertion from the Confederate army suggests only limited support for this sociological model. At the start of the war, desertion rates were, as the prevailing model would predict, greatest in highly heterogeneous companies, where social solidarity was lowest. But in the last two years of the war, men serving in companies with strong solidarity were significantly more likely to desert than men serving in heterogeneous companies. The positive association between social solidarity and desertion in the latter stages of the war is an unexpected result that provides insight into the process of identity formation and resistance to the war.

Over 12\% $(14,000)$ of the 110,000 men from North Carolina who served in the Confederate army deserted (Manarin \& Jordan 1966-1988). ${ }^{1}$ This rate was comparable to or lower than the rate for soldiers from other Confederate states. ${ }^{2}$ These soldiers must have had good reasons for leaving, but I show that desertion and individual interests are not related. Nor does desertion appear to be the response of anomic men to a crumbling social structure, as has been the case in other wars.

Despite these negative claims, we can understand Confederate desertions by focusing on the context of service, defined by the intersection of county of origin and company of destination. This analysis suggests a new model of the structural bases for the collapse of Southern morale. Desertion was driven by 
the resurgence of localist identities that the Confederate policy of coupling military and civil society organized and sustained.

\section{Civil and Military Society}

In wars, soldiers must assume risks in pursuit of collective goals that they would not pursue in everyday life. To gain compliance to command, armies must create a context in which the collective end (shooting people to gain control of a hill) is experienced as an individual end. This requires social solidarity. The norms governing social action must be shared. As we know, social relations are funnels through which norms flow. The basis of social solidarity in many primary groups, especially the army, is homogeneity of alters. In the modern army, homogeneity is induced by decoupling civil and military society; ${ }^{3}$ company solidarity is a by-product of this separation.

Ideally, men enter the army and soldiers exit the army. For this to occur, civil and military society must be decoupled; identity must be switched from one to the other. Various mechanisms of social control facilitate this shift: boot camp, the administration of collective sanctions and rewards at the company level, forced structural equivalence of individuals within ranks, and the transposability of soldiers from one setting to another are the most important (Heckathorn 1988). However achieved, the separation of civil and military society is fundamental to the creation of unit solidarity. By erasing traces of civil society as markers distinguishing individuals, the army induces homogeneity from a heterogeneous pool of recruits. The modern army thus resists the potentially disaggregative pressures of individual ends by eclipsing individuation.

Unlike modern armies, which seek to strip recruits of ties to civil society upon their enlistment to more fully embed them in the social world of the military, Civil War armies tried to induce social solidarity by the tight coupling of military and civil society. Thus, each company was organized within one county, and soldiers volunteered to serve with other men from their local area - many of them neighbors and kin. Even command was localist in orientation. Local elites organizing the company were placed in command and mustered in with the men they mobilized. The model army was an aggregation of separate local militias.

In the early years of the war, civil and military society remained tightly linked. But institutional pressures resulting from mortalities and exits led to the slow abandonment of the policy of coupling local communities with particular military units. As the war continued, many Confederate companies became increasingly heterogeneous with respect to their county of origin. Differences in the extent of heterogeneity and homogeneity of companies allow us to evaluate the role of social solidarity in inducing desertion.

The desertion rate in the heterogeneous companies was lower, especially following the summer of 1863 , than that of more homogeneous companies. And in the final two years of the war, desertion from the Confederacy was associated with increased company solidarity; the more localist the company, the higher the desertion rate. The Confederate strategy of tightly coupling military society 
and civil society appears to have undermined the capacity of the South to prosecute the war. Identities shaped in antebellum civil society resurfaced toward the end of the war, replacing the Confederate/Southern identity that had emerged in 1861 and that had initially propelled men into war.

\section{Organization}

I test interest-based theories of desertion that have been proposed by historians. These models assume that men deserted their companies to pursue interests in civil society, and they seek to identify similarities in the social backgrounds of deserters in order to impute motive. After rejecting these models, I test an identity-based model of desertion. First, I describe the data and sample and then discuss possible sources of selection bias that may confound the results presented.

\section{Data Sources and Sample Design}

The sample consists of 3,126 volunteer soldiers residing in North Carolina in 1860 and serving in Confederate regiments organized under North Carolina's authority. For each soldier, the following information is available from North Carolina Troops, 1861-1865: A Roster: name, age, county of birth and residence, date of and rank at enlistment, date(s) of desertion, promotion, imprisonment, whether the soldier was ever wounded, whether he was ever absent, and cause of death (Manarin \& Jordan 1966-1988). Since soldiers were paid every two months, a fairly reliable count of soldiers and events was recorded six times a year through late 1864 . After 1864, the quality of the data declines considerably and dates of events are less reliable, with a four- to six-month margin of error. ${ }^{4}$

I attempted to find a record of each soldier included in the sample in the 1860 federal census for North Carolina (U.S Bureau of the Census 1860). The manuscript census includes the name, age, literacy status, value of real and personal estate, gender, race, and occupation of each individual enumerated. Men were linked on the basis of name, age, county of birth, and county of residence. The structure of the 1860 manuscript census allows the researcher to reconstruct families within households. Every effort was made to reconstruct the families from which the sampled soldiers came, making the family of origin the primary domestic unit analyzed. By linking the data collected on soldiers from their compiled service records to the 1860 manuscript census, an individuallevel data set was created that combines social characteristics of men and the events they experienced.

The full data set consists of sampled individuals drawn from the North Carolina troop rosters (Manarin \& Jordan 1966-1988). In analyses where a desertion rate is calculated, the full sample is used. Analyses in which individual social-background characteristics are treated as independent variables - in order to model the determinants of desertion - the sample is reduced to soldiers who could be unambiguously located in the 1860 census. This population is referred to as the linked sample. 
The full sample is a random probability sample of $10 \%$ of all enlisted men serving in 208 randomly selected companies, men whose age and county of birth or county of residence were reported when they enlisted. Within each company, the sample was stratified by year of enlistment. ${ }^{5}$ As noted above, the full sample consists of 3,126 soldiers. Since $72.9 \%$ of the men in the full sample were linked to the 1860 manuscript census, the linked sample consists of 2,279 men. ${ }^{6}$ This sample $(N=2,279)$ is used to evaluate the individual-level theories of desertion. To evaluate the more detailed contextual hypotheses proposed, especially the role of neighborhood on desertion, service data for all soldiers ever serving in companies A or B of the 39th Regiment were gathered. Over $90 \%$ of these soldiers were linked to the 1860 census. These men are analyzed separately and not included in the linked sample analyses.

\section{SAMPLE SELECTIVITY}

The proportion of men found in the 1860 manuscript census is exceedingly high in comparison to other historical studies using census data. The main reason for such a high linkage rate is that all the men lived in North Carolina at enlistment, and all of them reported counties of residence or birth that were largely accurate guides to their residence at enlistment. Nevertheless, there may be reason to be concerned that selection bias could confound the results of this analysis.

Consider first biases resulting from an underenumeration of the census. The best available estimate is that the 1860 census in North Carolina underenumerated about $10 \%$ of the white population, a rate comparable to or lower than underenumeration in the U.S as a whole. As they are today, the causes of underenumeration are poverty and mobility. Both poverty and mobility rates are thought to have been higher in mountain counties during the period studied (Kenzer 1987), but no evidence supports regional bias in the probability of a link to the 1860 census. Likewise, the proportion of landless men in the linked sample $(40-50 \%)$ parallels estimates of the proportion of landless men in the South (Gallman 1970; Soltow 1975; Yang 1984). Selectivity resulting from underenumeration of the 1860 census seems minimal (Bode \& Ginter 1986).

Two other possible sources of selectivity bias are age and enlistment year. Young men may have pretended to be older at the point of enlistment; older men may have been unable to correctly report their year of birth. Misreports of age on the muster roles would make a link to the census difficult. In Table 1 (panel A) I report linkage rates for enlistment year by age cohorts. There is no significant association between age at enlistment and the rate of linkage to the 1860 census, although older men (at enlistment) are somewhat less likely to be found than younger men. Likewise, enlistment year could introduce some sample-selectivity bias. Since the census was taken in 1860 , we would expect that late enlistees would be harder to locate in the census than those who enlisted earlier, simply because more time had elapsed between the census and enlistment. Table 1 (panel B) shows the linkage rates for regions by year of enlistment. Note that regional differences in linkage rates are small across all 
TABLE 1: Proportion of Soldiers Linked to the 1860 Census

Panel A: By Age and Enlistment Year

\begin{tabular}{lrrrrrrrrr} 
& \multicolumn{9}{c}{ Enlistment Year } \\
& \multicolumn{1}{c}{1861} & \multicolumn{2}{c}{1862} & \multicolumn{1}{c}{$1863+$} & \multicolumn{2}{c}{ Total } \\
Age & $\mathrm{N}$ & $\%$ & $\mathrm{~N}$ & $\%$ & $\mathrm{~N}$ & $\%$ & $\mathrm{~N}$ & $\%$ \\
$<17$ & 62 & $(86.1)$ & 32 & $(91.4)$ & 5 & $(100.0)$ & 99 & $(88.4)$ \\
$17-19$ & 296 & $(76.7)$ & 179 & $(73.9)$ & 103 & $(79.2)$ & 578 & $(75.9)$ \\
$20-24$ & 423 & $(69.9)$ & 183 & $(64.2)$ & 31 & $(91.1)$ & 637 & $(68.9)$ \\
$25-29$ & 185 & $(73.7)$ & 176 & $(74.6)$ & 22 & $(52.4)$ & 383 & $(72.4)$ \\
$30-34$ & 100 & $(74.1)$ & 102 & $(63.7)$ & 22 & $(75.8)$ & 224 & $(69.8)$ \\
$35+$ & 104 & $(74.8)$ & 96 & $(69.1)$ & 157 & $(78.1)$ & 357 & $(74.5)$ \\
& & & & & & & & \\
Total & 1,170 & $(73.7)$ & 768 & $(70.0)$ & 340 & $(77.1)$ & 2,278 & $(72.9)$
\end{tabular}

Panel B: By Region and Enlistment Year

\begin{tabular}{lrrrrrrrr} 
& \multicolumn{9}{c}{ Enlistment Year } \\
& \multicolumn{1}{c}{1861} & \multicolumn{2}{c}{1862} & \multicolumn{2}{c}{$1863+$} & \multicolumn{2}{c}{ Total } \\
Region & $\mathrm{N}$ & $\%$ & $\mathrm{~N}$ & $\%$ & $\mathrm{~N}$ & $\%$ & $\mathrm{~N}$ & $\%$ \\
$\quad$ Mountains & 262 & $(68.8)$ & 133 & $(72.1)$ & 55 & $(73.7)$ & 450 & $(72.1)$ \\
Lower piedmont & 211 & $(78.7)$ & 191 & $(66.0)$ & 108 & $(81.5)$ & 510 & $(73.7)$ \\
Piedmont & 255 & $(70.0)$ & 192 & $(72.8)$ & 101 & $(64.7)$ & 548 & $(71.5)$ \\
$\quad$ Coastal plain & 326 & $(77.1)$ & 196 & $(66.7)$ & 51 & $(82.4)$ & 573 & $(73.2)$ \\
Coast & 116 & $(73.9)$ & 56 & $(90.1)$ & 25 & $(78.1)$ & 197 & $(75.5)$ \\
Total & 1,170 & $(73.7)$ & 768 & $(70.0)$ & 340 & $(77.1)$ & 2,278 & $(72.9)$ \\
\hline
\end{tabular}

five regions, the rates varying by only $3 \%$, and enlistment year is not statistically associated with the probability of a link to the 1860 census $\left(\chi^{2}=2.01, \mathrm{df}=3\right)$.

Selectivity is meaningful if the underlying selection occurs on a dimension associated with the dependent variable. Concern about bias resulting from poverty or age is reasonable because these are critical factors in the received historical accounts of desertion. Likewise, since enlistees after 1862 were subject to conscription if they did not volunteer first, they may have a different sentiment pool than those who enlisted earlier. No evidence suggests that the sample is biased with respect to these two variables (Downs 1982; Goff 1987).

Comparing across regions - using region as a proxy measure for differential embeddedness in the community - there is little evidence that the linked and full samples differ significantly in the proportion of deserters. As reported in Table 2, both samples have nearly the same proportion of deserters; the probability of finding a deserter appears largely independent of differential embeddedness in the community. 
TABLE 2: Proportion of Men Linked to the 1860 Census, by Region

\begin{tabular}{|c|c|c|c|c|c|c|}
\hline & Mountains & $\begin{array}{c}\text { Lower } \\
\text { Piedmont }\end{array}$ & Piedmont & $\begin{array}{c}\text { Coastal } \\
\text { Plain }\end{array}$ & Coast & Total \\
\hline $\begin{array}{l}\text { All men } \\
\text { Full sample }\end{array}$ & 624 & 692 & 766 & 783 & 261 & 3,126 \\
\hline $\begin{array}{l}\text { Linked sample } \\
\text { Percent }\end{array}$ & $\begin{array}{r}450 \\
72.1\end{array}$ & $\begin{array}{r}510 \\
73.7\end{array}$ & $\begin{array}{r}548 \\
71.5\end{array}$ & $\begin{array}{r}573 \\
73.2\end{array}$ & $\begin{array}{r}197 \\
75.5\end{array}$ & $\begin{array}{r}2,278 \\
72.9\end{array}$ \\
\hline $\begin{array}{l}\text { Deserters } \\
\text { Full sample }\end{array}$ & 153 & 26 & 76 & 86 & 39 & 380 \\
\hline $\begin{array}{l}\text { Linked sample } \\
\text { Percent }\end{array}$ & $\begin{array}{l}103 \\
67.6\end{array}$ & $\begin{array}{r}11 \\
41.1\end{array}$ & $\begin{array}{r}55 \\
72.5\end{array}$ & $\begin{array}{r}63 \\
73.7\end{array}$ & $\begin{array}{r}53 \\
84.6\end{array}$ & $\begin{array}{r}265 \\
69.9\end{array}$ \\
\hline $\begin{array}{l}\text { Desertion rate } \\
\text { Full sample (\%) } \\
\text { Linked sample (\%) }\end{array}$ & $\begin{array}{l}24.5 \\
22.9\end{array}$ & $\begin{array}{l}3.7 \\
2.2\end{array}$ & $\begin{array}{l}10.0 \\
10.0\end{array}$ & $\begin{array}{l}11.0 \\
11.0\end{array}$ & $\begin{array}{l}14.9 \\
16.8\end{array}$ & $\begin{array}{l}12.2 \\
11.6\end{array}$ \\
\hline
\end{tabular}

Note that in three of the five regions - mountains, piedmont, and coastal plain - deserters are as likely as stayers to be found in the 1860 census, whereas coastal deserters are more likely and deserters from the lower piedmont less likely to be found than stayers. Since the number of deserters from the lower piedmont is so small, establishing significance is difficult. I conclude from these data and other tests of sources of bias that selectivity effects resulting from record linkage are minimal.

\section{CODING DESERTION}

The apparently trivial question of classification - what is desertion - presents extremely thorny problems. As with suicide data, desertions are classified as such by others after the fact. According to the army, soldiers absent from their company without official leave for more than 60 days were classified as deserters. Men who were absent for fewer than 60 days were classified as AWOL. However, in many units, soldiers were carried on the company rolls as AWOL for the duration of the war, while in other companies the missing soldier would be classified as a deserter before the end of the 60-day AWOL period. Men classified as deserters were as likely to return to service as men classified as AWOL. Given substantial variance across companies, all soldiers classified as AWOL or as deserters are treated as deserters.

More complicated are soldiers who deserted through voluntary capture. These soldiers were coded as being captured, unless they subsequently renounced their positions in the Confederate army and swore allegiance to the Union, in which case they were coded as deserters. A large number of men are reported as "falling out of a march," but I did not code these men as deserters.

The determinants of capture and desertion are different, but the determinants of desertion and AWOL are similar, which suggests that the restrictive classification is appropriate for understanding the purposeful withdrawal of 
support for the war. Therefore, I focus on men whose actions were unambiguous to those whose job it was to keep track of loyalists and traitors.

\section{INDIVIDUAL-LEVEL ACCOUNTS OF DESERTION IN THE CIVIL WAR}

In this section I test interest-based accounts of desertion. The accounts tested are drawn from the historical literature and are reported as a series of hypotheses that cluster into three streams: economic hardship, family responsibility, and prior sentiment theories. Each cluster articulates aspects of the more general accounts of the collapse of the Confederacy. The economic hardship models focus directly on the role of class antagonism - predicting that desertion is associated with poverty and economic need. The family responsibility hypotheses suggest an interaction between class and family structure and argue that the experience of hardship was mediated by household and family composition. The prior sentiment models attempt to test more directly sentiment in favor of the Confederacy and the war effort. These hypotheses are reported below.

\section{Economic Hardship Theories}

Hypothesis 1. Desertion reflected recognition that the Civil War was a rich man's war and a poor man's fight and that a Southern victory would benefit only the elite. All other things being equal, poor men were more likely than rich men to desert (Auman 1988; Bardolph 1964; Lonn 1928; Reid 1981).

Hypothesis 2. Farmers were more likely than other occupational groups to desert because they were subject to the greatest hardships (Lonn 1928; Reid 1981; Tatum 1934).

Hypothesis 3. Farmer desertions were clustered during harvesting and planting seasons, when labor demands were acute (Auman 1988; Bardolph 1964; Lonn 1928).

\section{Family Responsibility Theories}

Hypothesis 4. Desertion reflected differential family responsibilities. Men with young dependent children at home were more likely to desert than those without young dependent children (Bardolph 1964; Lonn 1928; Reid 1981).

Hypothesis 5. Net of regional differences, dependent children in female-headed households were more likely to desert than those in male-headed households (Reid 1981).

Hypothesis 6. Older men were more likely than younger men to desert, all things being equal, since they were responsible for their families (Reid 1981).

\section{Prior Sentiment Theories}

Hypothesis 7. Late enlistees enlisted to prevent conscription, rather than from loyalty to the Southern cause. All things being equal, deserters were more likely than nondeserters to have enlisted later (Bardolph 1964; Lonn 1928; Honey 1986).

Hypothesis 8. Deserters deserted because they were cowards (Lonn 1928; Reid 1981).

Note that the predicted deserter is a late-enlisting, poor, cowardly farmer with dependent children at home. 
TABLE 3: Variables, Operationalizations, and Sources

\section{Measurement}

Desertion Coded 1 if deserted or AWOL, 0 otherwise (Manarin \& Jordan 1965-1988).

Region North Carolina is partitioned into five geographic regions that differ with respect to soil type, proportion black, proportion market agriculture, proportion slaveholder, and agricultural mode of production. Most work on North Carolina uses a similar partition. Coded as mountains, lower piedmont, piedmont, coastal plain, coast.

Enlistment date Logged enlistment date (Manarin \& Jordan 1965-1988).

Wealth

Dollar value of real estate owned by household heads. If dependent, dollar value of real estate owned by the household head (U.S. Bureau of the Census 1860).

Household head Head of household or dependent. Coded 1 if head of household, 0 if dependent child. Men living away from their family of origin (or destination) are coded as dependents (U.S. Bureau of the Census 1860).

Age Age at enlistment (U.S. Bureau of the Census 1860).

Occupation Partitioned into five unordered categories: farmer, farm laborer, professional, skilled laborer/craftsman, unknown (U.S. Bureau of the Census 1860).

Female-headed Coded 1 if dependent child resided in a female-headed household, household 0 otherwise. Boys living away from their family of origin were coded 0 (U.S. Bureau of the Census 1860).

Birth order Coded 1 if eldest son, 0 if younger son. Only sons were classified as eldest sons (U.S. Bureau of the Census 1860).

Dependents Number of dependents under the age of 12 living in the home of soldiers who were head of household (U.S. Bureau of the Census 1860).

Cowardice Tenure in months from enlistment to desertion (Manarin \& Jordan 1966-1988).

\section{MEASUREMENT}

Table 3 reports variables, operationalizations, and sources for each variable used to evaluate the hypotheses listed above. Figure 1 is a map of North Carolina showing regions as they are defined in this article.

Results of a logistic regression of desertion as a dependent variable are reported in Table 4. From this table, one can see that net of regional effects, which are pronounced, no individual-level characteristic is statistically or substantively associated with desertion. These data do not support the economic hardship or family responsibility hypotheses (hypotheses 1 through 4). Region, 


\section{FIGURE 1: North Carolina Regions, 1860}

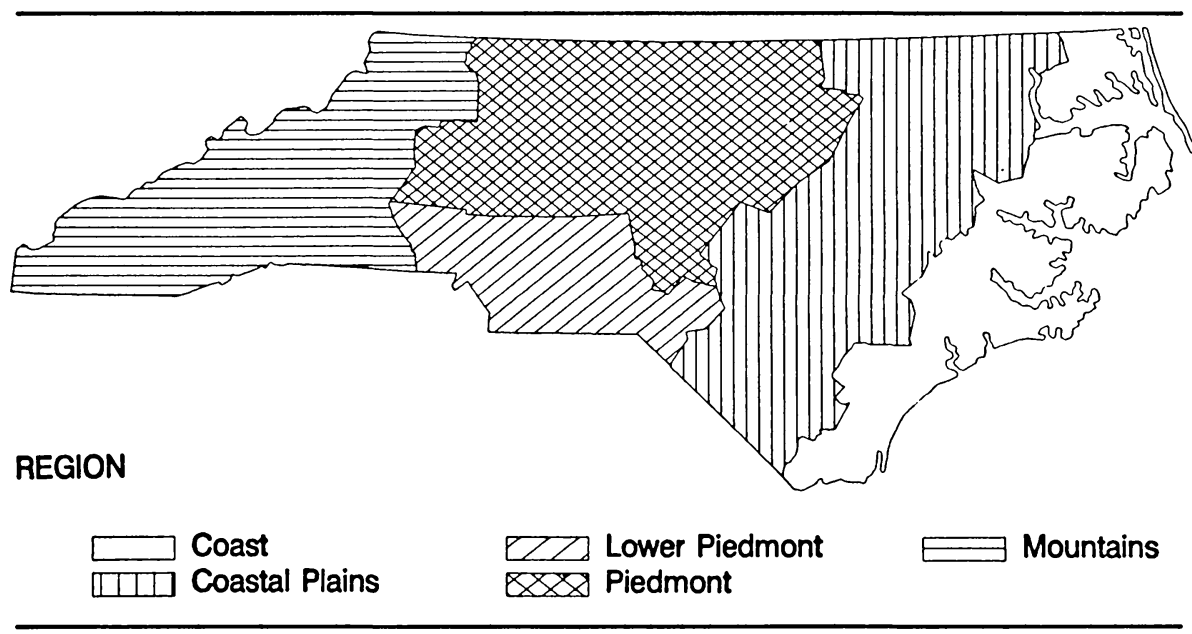

used as a control, is the only variable associated with desertion. For example, soldiers from the mountains (in 1860) are nine times as likely to desert than men living in the lower piedmont, and more than four times as likely to desert than men from the coastal plain (slavebelt), piedmont, or coast. Net of region, no coefficient is even close to statistical significance. The only one that appears close to substantive significance is farm laborer: relative to farmers, farm laborers were twice as likely to desert (prob.=.089). Controlling for wealth, this result appears to reflect differential embeddedness in a community arising from control over land, suggesting that deserters were less embedded than stayers in local communities, but the relationship is weak. Interpreting these results is a tenuous activity at best.

Wealth is not associated with desertion. Soldiers with small holdings and those with substantial holdings deserted at the same rate, all other things being equal. Neither economic hardship nor class bitterness played a role in determining desertion.

The family responsibility hypotheses fare no better than the economic hardship theories. Age at enlistment is not related to desertion. Younger sons are more likely to desert than firstborn sons, but the relationship is not significant. Some evidence suggests that dependents from female-headed households may have been less likely to desert than dependents from households headed by males. Heads of households are twice as likely to desert than dependents (prob.x.119). While not statistically significant, this relationship appears to be stronger than many others. The number of dependents in the household is not related to the probability of desertion. Thus, family responsibility arguments are not supported by these results.

Relative to soldiers enlisting during the first month of the war, later enlistees are slightly more likely to desert, net of age and service tenure. Preexisting antiwar sentiment reflected by delayed enlistment is not associated with desertion. The late volunteers may have been less enthusiastic about war 
TABLE 4: Logistic Regression of Desertion: Individual Attributes

\begin{tabular}{lrrrrr}
\hline & $\beta$ & Std. Error & \multicolumn{1}{c}{$\chi^{2}$} & Prob & $R$ \\
Intercept & & & & & \\
& -1.540 & .544 & 8.02 & .005 & \\
Lower piedmont & & & & & \\
Piedmont & -2.630 & .542 & 23.52 & .000 & -.185 \\
Coastal plain & -.876 & .297 & 8.68 & .003 & -.103 \\
Coast & -.944 & .292 & 10.38 & .001 & -.116 \\
& -.511 & .292 & 1.73 & .188 & .000 \\
Enlistment date & & & & & \\
Wealth & -.105 & .146 & .51 & .473 & .000 \\
Household head & -.000 & .000 & 1.14 & .285 & .000 \\
Age & .464 & .297 & 2.44 & .119 & .026 \\
& .010 & .017 & .40 & .528 & .000 \\
Farm laborer & & & & & \\
Skilled laborer & .499 & .288 & 2.89 & .089 & .038 \\
Professional & .372 & .438 & .72 & .396 & .000 \\
Unknown & .011 & .594 & .00 & .984 & .000 \\
Female-headed household & -.159 & .140 & 1.28 & .258 & .000 \\
Birth order & .017 & .013 & 1.22 & .269 & .000 \\
& & & & & \\
\hline
\end{tabular}

than the men who enlisted before them, but they were not more likely to desert as a result of their prior beliefs. Thus, hypothesis 7 is rejected.

Net of region, no single individual-level attribute is strongly associated with desertion. Theories of desertion that derive their energy from variances in individual characteristics - and use these variances to impute differences in interest - are clearly falsified by these results. Also, these data do not support the new historical models that suggest that structural cleavages crosscut and corroded an ephemeral Southern nationalism.

\section{Temporal Variation}

The idea that there was substantial variation in the timing of desertion in the Civil War has provided grist for a number of mills. A classic account of Confederate deserters is that they were poor subsistence farmers who left the front to tend to the family farm during planting and harvesting seasons (Bardolph 1964; Lonn 1928). This oddly romantic theory is also falsified. As shown above, poverty is not associated with desertion. Likewise, there are no obvious seasonal effects. Table 5 reports the seasonal distribution of desertions for all men, for farmers and farm laborers, and for farmers and farm laborers who returned to their companies after deserting or being listed as AWOL. Men deserting in the spring or fall may have worked on their farm, but the seasonal pattern of desertion does not support the theory that desertion was motivated by the seasonal demands of agriculture. Desertion was independent of season. Thus, hypothesis 3 is rejected. 
TABLE 5: Proportion of Soldiers Deserting, by Season, 1861-1865

\begin{tabular}{lcccc}
\hline & Spring & Summer & Fall & Winter \\
Category & & & & \\
$\quad$ All soldiers & 23.8 & 25.4 & 26.3 & 22.9 \\
Farmers and farm laborers & 19.7 & 26.6 & 28.8 & 24.9 \\
Returning farmers & 21.3 & 25.9 & 27.4 & 25.4 \\
\hline
\end{tabular}

\section{Service Tenures}

Patterns in service tenures prior to desertion may help support a theory of motivation. Historians have suggested that desertion may reflect cowardice (Lonn 1928; Tatum 1934). I do not know how to measure this concept. One strategy is to search for a positive association between company desertion rates and company mortality rates: quarterly company mortality does not predict desertion in the subsequent quarter. A second strategy is to focus on variance in lengths of service prior to desertion: mean tenure of stayers did not differ significantly from that of deserters ( 25 months vs. 19 months). Because service tenures of stayers and deserters are so similar, I reject the hypothesis that deserters were cowards. Note that the fact that the mean tenure for deserters is an artifact of their desertion (if they had not deserted, they would have served longer) does not undermine rejection of hypothesis 8 .

Interestingly, soldiers deserting within the first year of enlistment differ very little from soldiers with longer tenures who deserted. Net of age, no individual attribute predicts the timing of desertion. Enlistment year, literacy, the dollar value of real estate, occupation, the number of dependents at home, the number of siblings at home, female-headed household, personal wealth, and birth order are not significantly associated with length of service prior to desertion. Mean tenures appear to be associated with age, but all we can see from this association is that boys who deserted were braver than men who deserted.

These results reject every individual-level hypothesis proposed to account for Southern desertion in the Civil War. Stayers and deserters look very similar with respect to class, occupation, age, family composition, and enlistment date. Interest as structured by the occupancy of differential positions in civil society cannot account for desertion. It would be hard to defend an interest-based theory of motivation based on these marginal results.

\section{Contextual Determinants of Desertion}

Knowledge about individual social-background characteristics is not useful for understanding desertion in the war. On the other hand, a number of contextual variables appear important as determinants of desertion. In this section, I start with broad contexts - region, county group, and county - and then focus on more proximate contexts in which men experienced the war - company of destination and community of origin. From this analysis, I identify a general contextual variable, localism, and show its strong effect on desertion rates. 
Consider first the overwhelming regional differences in the desertion rate as reported in Table 4. All other variables being equal, soldiers from the mountains were more than four times as likely to desert than soldiers from any of the other regions. On the other extreme, the desertion rate for enlisted soldiers from the lower piedmont, the area bordering South Carolina, was fully three times less than the state average. In the coastal plain (slavebelt), where support for slavery might logically be presumed to be widespread, men deserted at roughly the state average. Historians have developed numerous compelling arguments explaining the regional effects on desertion in the South in general and North Carolina in particular. These tend to focus on a cluster of interrelated ideological, economic, and social factors that are regionally distributed (Bardolph 1964; Lonn 1928; Reid 1981).

Bardolph (1964) argues, for example, that regional variation of the importance of slavery in North Carolina accounts for the observed differences in the desertion rate. Operationalizing county embeddedness in the slave economy as the proportion of the white population owning slaves, following Auman (1988), no association is found between county desertion rates and county involvement in the slave economy. Other measures fare poorly as well; neither proportion black nor the average size of each slaveholding is associated with countyspecific desertion rates. At best, these variables account for less than $2 \%$ of the variance.

Regional variation in the proportion of slave owners yields an uneven pattern. The high desertion rate in the mountains is associated with a lower slave-ownership rate (less than 3\% of the white population owned slaves) suggesting some support for the argument that desertion rates were highest in areas where slavery was least important - but this association does not hold for the coast. In the coastal plain, where the proportion of slave owners is close to $10 \%$, the desertion rate was almost three times higher than that of the lower piedmont, where only $7 \%$ of the white population owned slaves (U.S. Bureau of the Census 1860).

Nor is it clear why there should be a relationship between slave-ownership and desertion rates. In 1860, the average price paid at auction for an adult slave was $\$ 1,800$ (Taylor 1926). At the same time, the typical adult head of household controlled assets valued under $\$ 500$ in combined real and personal wealth (U.S. Bureau of the Census 1860). Well over $90 \%$ of enlisted men owned no slaves, had no hope of purchasing one, ${ }^{7}$ and were not directly embedded in the slave economy.

Reid (1981) argues that the political and ideological traditions of each region are crucial elements in determining the likelihood of desertion. As election returns indicate, men living in the mountains were more likely than men from any of the other regions (particularly the piedmont or the coastal plain) to vote Republican in both local and national elections. Prior to secession, Unionist sentiment was more widespread and stronger in the western mountain region than in the eastern regions of the state (Crawford 1989; Kruman 1983).

While Union sentiment was widespread in the more Republican mountains, it does not necessarily follow that the general diffusion of pro-Union sentiment 
in the west can account for the high rate of desertion. One indicator of support for the war is the proportion of early enlisters. In the mountains, a greater proportion of men enlisted in the early years of the war than did men from the lower piedmont, where the desertion rate was extremely low (Crawford 1989; Reid 1981).

Support for the war in Ashe County (in the mountains) was overwhelming once North Carolina seceded, despite powerful Unionist political sentiment (Crawford 1989). Nor can one observe either abnormally low enlistment rates or abnormally high desertion rates in other areas outside the mountains, where Republicanism was strong (Kenzer 1987). As Crawford's study of Ashe County suggests, men did not distinguish between purely local and national politics. Secession and war mobilized men as Southerners and gave them an identity broader than the local community, but for many it held only a fleeting reality (Crawford 1989).

Regional differences in desertion rates correspond somewhat to expected patterns, lending credence to a model of crosscutting cleavages in a nascent nationalism as core determinants of the withdrawal of war support. But the relationships fall apart at the county level, suggesting that desertion was in other ways uniquely localist. Understanding desertion may require that one consider how community effects were mediated through the army-company context. Company solidarity emerges as the key element.

\section{LOCALISM: COMPANY SOLIDARTTY, HOMOGENETTY, AND DESERTION}

I consider the desertion rate over time - from 1861 to the end of the war - in relation to company homogeneity and define homogeneity with respect to county of origin, such that companies composed of men from only one county are homogeneous and companies composed of men from many different counties are heterogeneous. In Table 6, I report the number of desertions across selected periods of the war for companies categorized by degree of homogeneity.

For each observed desertion in the sample, I derive a measure of company heterogeneity for the month the desertion occurred. Thus, Table 6 reports the number of desertions that occurred in each period by the time-specific company-heterogeneity context in which the desertion occurred. Since company heterogeneity was a product of prior events within the company - mortalities and desertions, new recruits and absences - companies did not retain a given heterogeneity score across all months of the war.

Cell entries in Table 6 indicate the raw number and the row and column proportion of desertions for companies arrayed by their heterogeneity at the time of desertion. Reading across the first row, which reports desertions for the most heterogeneous companies, note that the proportion of men who desert decreases over time from $41 \%$ during months $1-18$ to $14 \%$ and $7 \%$ during months $31-42$ and $43-50$, respectively. In contrast, note that the pattern of desertions in homogeneous companies, reported in the third row, is the reverse. Over the course of the war, desertions in homogeneous companies increase markedly, from 21\% in the first 18 months to 58\% in the last period. This reversal is more striking given that, as reported in the last row, the proportion of homogeneous companies decreased, from $64 \%$ to $29 \%$, over the four years of 
TABLE 6: Company Heterogeneity and Desertions, by Period ${ }^{a}$

\begin{tabular}{|c|c|c|c|c|c|c|}
\hline & \multicolumn{6}{|c|}{ Desertion Months } \\
\hline & $1-18$ & $19-24$ & $25-30$ & $31-42$ & $43-50$ & Total \\
\hline & \multicolumn{6}{|c|}{ High (.5 to .72$)$} \\
\hline $\mathrm{N}$ & 16 & 12 & 10 & 6 & 4 & 48 \\
\hline Row percent & 33 & 25 & 21 & 12 & 8 & \\
\hline Column percent & 41 & 33 & 20 & 14 & 7 & \\
\hline \multicolumn{7}{|l|}{ Medium (.25 to .49$)$} \\
\hline $\mathrm{N}$ & 15 & 16 & 17 & 16 & 13 & 77 \\
\hline Row percent & 19 & 21 & 22 & 21 & 17 & \\
\hline Column percent & 38 & 44 & 34 & 37 & 32 & \\
\hline \multicolumn{7}{|l|}{ Low (0 to .25) } \\
\hline $\mathrm{N}$ & 8 & 8 & 23 & 21 & 23 & 83 \\
\hline Row percent & 9 & 9 & 28 & 25 & 28 & \\
\hline Column percent & 21 & 22 & 46 & 49 & 58 & \\
\hline Total & 39 & 36 & 50 & 43 & 40 & 208 \\
\hline Percent & 19 & 17 & 24 & 20 & 19 & \\
\hline Percent Homogeneous & 64 & 55 & 38 & 31 & 29 & 157 \\
\hline
\end{tabular}

' Heterogeneity $=1-\left[(a / z)^{2}+(b / z)^{2}+(c / z)^{2} \ldots\right]$, where $a, b, c \ldots$ represent the number of men in each company from a given county, and $z$ represents the number of men in the company (Finke \& Stark 1988).

the war. The pattern of increasing desertions over time in homogeneous companies is statistically significant at the .005 level $\left(\chi^{2}=23.64, \mathrm{df}=8\right)$.

A clear interpretation of these data is that early deserters typically deserted heterogeneous companies and late deserters deserted homogeneous companies. This finding is not predicted by the classical sociological models of desertion that maintain that solidarity within the primary unit uniformly conditions desertion (Shils \& Janowitz 1948). At the start of the war, Confederate deserters - unlike their counterpart stayers - were disproportionately egoistic, serving in companies without ties to other men from their county. The absence of these ties severed commitment to the army. Companies most distant from civil society had the highest desertion rates.

Yet toward the second half of the war, increased solidarity yielded an increased desertion rate. Solidarity in homogeneous companies tightly coupled with local county society articulated localist identity in opposition to the Confederate ideal. By fall 1863, the tight coupling of civil and military society motivated desertion. Ironically, companies composed of men who had the longest tenures, who were the most experienced, and who had the greatest solidarity were most likely to have the highest desertion rates after 1863. 
Erosion of support for the war, at home and on the front, must have generated this pattern. Men who were still tied to civil society and who, by virtue of those ties, were able to resist a military identity, were more likely to view themselves as members of civil society and consequently to desert. Here we see the process of identity formation, where men still bound to civil society used these ties to propel them out of service. On the other hand, soldiers serving in heterogeneous companies, stripped of close ties to civil society, were more completely bound into military society and consequently less likely to renounce the command structure of the army. By the end of 1863, stayers were egoistic men serving time in an increasingly disaggregated social structure.

\section{NEIGHBORHOOD UNDERLYING COUNTY AS BASIS FOR LOCALISM}

In 1860 , most counties in North Carolina had a white population under 10,000. Still, counties were large spatial units, and we should consider whether social relations were organized at the county level or if neighborhood effects underlay the county effects reported in Table 6. To assess neighborhood effects on desertion, I developed a supplementary saturated sample of all men serving in two companies drawing recruits mainly from Jackson and Macon counties in the mountains. ${ }^{8}$

In addition to the variables discussed above, I recorded the household number of each household as reported in the census. Men who gathered the census walked across each county, stopping at all households. Although error is possible if the census taker took a circuitous path, I assume that households with sequential census numbers were spatially close (Kenzer 1987). Households in named communities were almost always listed sequentially. If neighborhood underlies county as the source of social solidarity, late deserters are expected to be clustered into spatially close households. Early deserters ought to be spatially disjoint.

Table 7 (panels A and B) reports for companies A and B the neighborhoods of men in the census and the number of early (April 1861 to June 1863) and late (July 1863 to the end of the war in 1865) deserters for each community. Each cell shows the number of stayers, early deserters, and late deserters for a cluster of households.

These data suggest that the households of late deserters are clustered in a few communities, whereas early-deserter households are dispersed. Note that the communities of households numbered 279-368 and 754-897 in company B provide over $87 \%(14 / 16)$ of the late deserters, compared to $43 \%(3 / 7)$ of the early deserters. In company $A$, all the late deserters were from two communities, whereas the early deserters were more evenly dispersed. Although limited to two cases, these data strongly suggest that community neighborhoods underlay counties as the determinant of identity in civil society. Where local identities were carried into the army, the Confederacy was subject to their resurgence. While localism appears at the county level as a strong correlate of desertion, these data suggest that county (in 1860, as today) is a weak proxy for social solidarity. Clearly, we need more studies of the role of localism in this context. 
TABLE 7: The Spatial Distribution of Deserters: Household Number in the 1860 Census and Desertion

Panel A: Company B, 39th Regiment

\begin{tabular}{lcccccc} 
& \multicolumn{5}{c}{ Household Number } \\
$\begin{array}{l}\text { Number } \\
\begin{array}{l}\text { Deserting in } \\
\text { months 1-24 }\end{array}\end{array}$ & $1-186$ & $187-278$ & $279-368$ & $369-625$ & $626-753$ & $754-897$ \\
$\begin{array}{c}\text { Deserting in } \\
\text { months 25-40 }\end{array}$ & 2 & 0 & 1 & 1 & 2 & 1 \\
Not deserting & 13 & 15 & 8 & 13 & 16 & 6 \\
\hline
\end{tabular}

Panel B: Company A, 39th Regiment

\begin{tabular}{lcccc} 
Number & \multicolumn{4}{c}{ Household Number } \\
$\begin{array}{l}\text { Deserting in } \\
\text { months 1-24 }\end{array}$ & $1-400$ & $401-700$ & $701-1100$ & $1101-1429$ \\
$\begin{array}{l}\text { Deserting in } \\
\text { months 25-40 }\end{array}$ & 9 & 1 & 1 & 2 \\
Not deserting & 20 & 0 & 0 & 5 \\
\hline
\end{tabular}

\section{Discussion}

Desertion is the flip side of enlistment, for just as a person may elect to leave civil society and enter the army, the deserter elects to leave military society and return home. About $80 \%$ of the men from North Carolina aged 15-49 left their families and homes to join the Confederate army (Manarin \& Jordan 1966-1988; U.S. Census 1860). The majority enlisted at the first opportunity in a wave of enthusiasm for the Southern cause. They saw themselves as Southerners and embraced a crusade for Southern rights.

Most volunteered for the duration of the war believing that they would return home triumphantly within a year (Barrett 1963). Few had a realistic sense of what they would face. While on the train taking him to the front in March 1861, Thomas Gaither wrote his father, "We have the joliest [sic] crowd that I ever saw"; within two weeks he wrote his brother, "Be satisfied at home as long as possible for this is know [sic] place for to come. ... Ever boddy [sic] is anxious for this war to close" (Hardy n.d.:5-9). In less than a month he was anxious to leave (Hardy n.d.). Such sentiments were typical.

After mobilization, most men experienced severe privations, serving without adequate food, warm clothing, and shoes for long periods of time (Barrett 1963; Lonn 1928). Contaminated drinking water, inadequate sanitation, and insufficient food supplies led to epidemics that accounted for more than $50 \%$ of all mortalities. At the front, the war experience was worse. Even by our modern 
standards, Civil War battles were gruesome affairs (McPherson 1988). Fully a third of North Carolina soldiers died in the Civil War. Not surprisingly, some men left early by deserting. Others may have wanted to desert but ended up as "stayers" who were killed in combat.

Those who left had their reasons, or so we suspect. About 14,000 men deserted before the war ended, and most theories about why they deserted are derived from their ex post facto accounts, formed in a setting where desertion was nonnormative. In the historical literature, individual reasons are seen as motives representative of whole categories of individuals. Not surprisingly, the Southern rhetoric about desertion in the postwar years emphasized hardship and class bitterness as motives. Nor is it surprising that romantic images of the rebel farmer - sneaking home to plant and harvest and then returning to battle when needed - were as attractive to historians as they were to contemporaries, for these are long-standing rhetorical themes in Southern culture. Despite the rhetorical persuasiveness of these individual-level accounts, I have found not one individual-level social characteristic statistically associated with desertion. Nevertheless, we can distinguish stayers and deserters by examining the social context of desertion, because this was the concrete setting in which social identity was defined.

When the war was just starting, the typical deserter served in an anomic, weakly integrated company. As the war dragged into the third year, soldiers serving in companies composed largely of men from the same county and neighborhoods deserted. For these men, their localist identities as members of civil society gained ascendancy over a competing Confederate nationalist identity.

In war, soldiers are expected to sacrifice their own ends to achieve a collective good. In most cases, social solidarity at the unit level has been shown to contribute to identity as a soldier (over competing identities derived from memberships in civil society). But social relations are funnels through which norms and values of all sorts flow. Just as in factories (where social relations may induce workers to increase or decrease the production of goods), in armies unit solidarity may induce greater commitment to army goals, but not necessarily. If the collective is defined on a basis different from the military, soldiers may pursue ends quite different from those expected.

The irony of the Civil War for the Confederacy is that the tightly localist social organization of the army - which induced mass mobilization in response to powerful community sentiments - led to desertion as the impact of fighting a losing war began to be experienced at home and on the front. The same localisms that first drew men into the Confederate army later drew them away from the Southern cause and back toward home.

\section{Notes}

1. If not otherwise cited, all facts about soldiers from North Carolina reported here are developed by the author and refer to conclusions generalized from the unlinked and linked sample.

2. For most Southern states, data are not available to directly estimate the desertion rate for their troops. Comparing the rate of desertions to mortalities by states is possible, however. With this metric, North Carolina has one of the lowest desertion rates, second only to South Carolina. Desertion was highest (relative to mortality) in the western Confederacy - Arkansas, Alabama, and Texas, for example. 
3. This process occurred in early bureaucracies that were staffed by individuals who had no social relations with other men in civil society. The classical bureaucracies were staffed by slaves and eunuchs, both socially dead. More modern bureaucracies induce loyalty with more subtlety. Clerics renounce ties to civil society through celibacy, and modern bureaucracies separate the ownership of an office from its administration (Patterson 1982; Weber 1978).

4. After 1864, the quality of the data reported in the troop rosters declines considerably. Where no information on a soldier appears, I presume that he was present until the end of the war.

5. Fewer than $20 \%$ of the men enlisting after 1864 had county of residence or age reported at enlistment. Since linkage to the census was in large part determined by these two characteristics, only soldiers with these identifiers were sampled for the 1864-1865 enlistment cohorts. There is no reason to suspect that this shift in sampling strategy results in any bias.

6. There are a number of good reasons for an exceptionally high linkage rate. Unlike other wars, which tend to recruit from the most disadvantaged sectors of the population, $80 \%$ of the men from North Carolina aged 15-49 in 1860 served at some time during the Civil War. Since a wide cross-section of the population served in the army at some occasion, the probability of finding a soldier in a census is much greater than that associated with other wars. Second, the vast majority of men enumerated in the troop rosters resided in North Carolina at the time of their enlistment, during the years 1861-1865. Backward linkage is associated with a greater probability of success than forward linkage.

7. Another measure of county involvement in the slave economy is that of inequality in slaveholdings. Inequality may be operationalized as a gini index. A gini score may be interpreted as a measure of social cleavage. High scores are associated with greater social cleavage, since in the hypothetical case where one person controls all resources, the score is 1 , and where all men in the population share equally, the score is 0 . A reasonable hypothesis is that the desertion rate was higher in regions where inequality in slaveholding was greatest, because the social gulf between slaveholders and nonslaveholders was larger. Both county and regional inequality scores mirror fairly closely the region-specific desertion rate, highest in the mountains $(.87)$, followed by the coast (.79), coastal plain (slavebelt) (.73), piedmont (.71), and lower piedmont (.63). Most enlisted men did not own a slave, but in regions where slave ownership was highly skewed, the desertion rate was highest. Some of the regional effect may be attributed to this difference (Wright 1970).

8. The higher linkage rate for this subsample results from the careful work of Richard Melvin, who has been tracking men from the 39th Regiment for years through the census.

\section{References}

Auman, William T. 1988. "Neighbor Against Neighbor: The Inner Civil War in the Central Counties of Confederate North Carolina." Ph.D. diss., Department of History, University of North Carolina at Chapel Hill.

Bardolph, Richard. 1964. "Inconstant Rebels: Desertion of North Carolina Troops in the Civil War." North Carolina Historical Review 41:163-89.

Barrett, J.G. 1963. The Civil War in North Caroline. University of North Carolina Press.

Beringer, Richard, Herman Hattaway, Archer Jones, and William Still. 1986. Why the South Lost the Civil War. University of Georgia Press.

Bode, Frederick, and Donald Ginter. 1986. Farm Tenancy and the Census in Antebellum Georgia. University of Georgia Press.

Crawford, Martin. 1989. "Political Society in a Southern Mountain Community: Ashe County, North Carolina, 1850-1861." Journal of Southern History 55:373-90.

Donald, David. 1960. An Excess of Democracy; The American Civil War and the Social Process. Clarendon Press.

Downs, Alan. 1982. "Enlistment into Confederate Service: The First Regiment North Carolina State Troops As a Test Case." Master's thesis, Department of History, University of North Carolina at Chapel Hill. 


\section{2 / Social Forces 70:2, December 1991}

Durden, Robert. 1972. The Gray and the Black: Confederate Debate on Emancipation. Louisiana State University Press.

Durkheim, Emile. 1951. Suicide: A Study in Sociology. Free Press.

Escott, Paul. 1978. After Secession: Jefferson Davis and the Failure of Confederate Nationalism. Louisiana State University.

Escott, Paul, and Jeffrey Crow. 1986. "The Social Order and Violent Disorder: An Analysis of North Carolina in the Revolution and the Civil War." Joumal of Southem History 52:373-402.

Finke, Roger, and Rodney Stark. 1988. "Religious Economies and Sacred Canopies: Religious Mobilization in American Cities, 1906." American Sociological Review 53:41-49.

Gallman, Robert E. 1970. "Self Sufficiency in the Cotton Economy of the Antebellum Snuth." Agricultural History 44:5-23.

Goff, Jerry C. 1987. "The Geographic Origins of North Carolina Enlistments in the War between the States." Master's thesis, Department of History, University of North Carolina at Chapel Hill.

Hardy, Elizabeth. N.d. "The Civil War Letters of the Gaither Family." North Carolina Historical Collection, University of North Carolina, Chapel Hill.

Heckathorn, Douglas. 1988. "Collective Sanctions and the Creation of Prisoner's Dilemma Norms." American Joumal of Sociology 94:535-62.

Honey, Michael K. 1986. The War Within the Confederacy: White Unionists of North Carolina. Washington, D.C.: National Archives Trust Fund Board.

Kenzer, Robert C. 1987. Kinship and Neighborhood in a Southern Community: Orange County, North Carolina, 1849-1881. University of Tennessee Press.

Kruman, Marc. 1983. Parties and Politics in North Carolina. Louisiana University Press.

Lonn, Ella. 1928. Desertion During the Civil War. Century Company.

Manarin, Louis H., and Weymouth T. Jordan (eds.). 1966-1988. North Carolina Troops, 1861-1865: A Roster. 11 vols. Division of Archives and History, North Carolina Department of Cultural Resources, Raleigh.

McPherson, James C. 1982. Ordeal by Fire: The Civil War and Reconstruction. Knopf. 1988. Battle Cry of Freedom: The Civil War Era. Oxford University Press.

Owsley, Frank. [1925] 1961. State Rights in the Confederacy. Peter Smith.

Patterson, Orlando. 1982. Slavery and Social Death: A Comparative Study. Harvard University Press.

Reid, Richard. 1981. "A Test Case of the 'Crying Evil': Desertion Among North Carolina Troops in the Civil War." North Carolina Historical Review 58:234-62.

Shils, Edward, and Morris Janowitz. 1948. "Cohesion and Disintegration in the Wehrmacht." Public Opinion Quarterly 2:280-315.

Soltow, Lee. 1975. Men and Wealth in the United States. Yale University Press.

Stouffer, Samuel A., Edward A. Suchman, Leland C. DeVinney, Shirley A. Star, and Robin M. Williams, Jr. 1949. The American Soldier: Combat and Its Aftermath. Princeton University Press.

Tatum, Georgia Lee. 1934. Disloyalty in the Confederacy. University of North Carolina Press.

Taylor, R.H. "Slaveholding in North Carolina: An Economic View." James Sprunt Historical Publications 18(1):1-103; 18(2):73-4.

U.S. Bureau of the Census. 1860. Eighth Census of the United States, 1860. Govemment Printing Office.

Watson, Harry. 1985. "Conflict and Collaboration: Yeomen, Slaveholders and Politics in the Antebellum South." Social History 10:273-98.

Weber, Max. [1922] 1978. Economy and Society. University of California Press.

Wiley, Bell Irvin. 1943. The Life of Johnny Reb: The Common Soldier of the Confederacy. Bobbs-Merrill.

Wright, Gavin. 1970. "Economic Democracy and the Concentration of Agricultural Wealth in the Cotton South, 1850-1860." Pp. 63-93 in The Structure of the Cotton Econony of the Antebellum South, edited by William Parker. Washington, D.C.: Agricultural History Society.

Yang, Donghyu. 1984. "Notes on the Wealth Distribution of Farm Households in the United States, 1860: A New Look at Two Manuscript Census Samples." Explorations in Economic History 21:88102. 